\title{
THE ANALYSIS OF TOPENG SINOK DANCE IN BREBES REGENCY
}

\author{
Dinar Ayu Sintho Rukmi* \\ Indriyanto $^{* *}$ \\ $\bowtie$ A Dancer and a Teacher in Brebes Regency, Indonesia \\ *E-mail: dinar_ayu@yahoo.com \\ Dance Department of Semarang State University, Indonesia \\ ${ }^{* *}$ E-mail: indriyanto609@gmail.com
}

Received: April 22, 2015. Revised: May 5, 2015. Accepted: June 13, 2015

\begin{abstract}
Topeng Sinok dance is the characteristic art of Brebes regency. This dance tells about the typical women in Brebes who are hard-working. Beauty, flexibility, and elegance do not reduce their love for nature and farming. This dance is a combination of Cirebon, Banyumas, and Surakarta style. The dance is basically aiming at showing that women from the border areas of Central and West Java are not spoiled, whiny, and lazy. Topeng Sinok dance is performed beautifully, elegant, and swift. This paper purposes to uncover the meaning behind Topeng Sinok dance movement. This study implements qualitative method that uses qualitative descriptive approach. The data collection process was conducted by using observation, documentation, and interview techniques. Further, the data were analysed by using dance data analysis by following the steps of (1) identifying and describing components; (2) understanding; (3) interpreting; and (4) evaluating. The data were then validated by using triangulation.
\end{abstract}

Keywords: Dance style; Choreography; Topeng Sinok

How to Cite: Rukmi, D. A. S., \& Indriyanto. (2015). The Analysis of Topeng Sinok Dance in Brebes Regency. Harmonia: Journal Of Arts Research And Education, 15(1), 25-33. doi:http://dx.doi.org/10.15294/harmonia.v15i1.3693

\section{INTRODUCTION}

Each dance has its own beauty which becomes the characteristic of the dances itself. It makes them different from one to another. The typical characteristic of the dance itself is usually found in its choreography, which consists of both visual and auditive aspects (Adshead, 1988, p. 24). The visual aspect comprises: movements, make up, the dancers, as well as the dance properties. Whereas the auditive aspect encompasses the music accompaniment as well as the sound system (Murgiyanto, 2002, p. 9). Those choreography aspects can also be found in Topeng Sinok dance.
Topeng Sinok dance is one of a traditional dance from Brebes regency, Indonesia. This dance is created by Suparyanto, S. Kar, an art council from Brebes regency. As other dances, this dance also has meanings and messages in each performance. The term 'Sinok' from Topeng Sinok dance is actually the term used by local elder to call for girls from their regency. This dance tells about women to live in Brebes regency, who are generally hard-working. With their beauty, flexibility, and elegance, they take care of their nature by working as farmers. This dance is an art combination between Cirebon, Banyumas, and Surakarta. In other words, this dance wants to show 
to people that women in Brebes regency are not spoiled, whiny, and lazy. Working as farmers, getting burned because of the sunshine do not limit them to be active, vivacious, and jovial in manners. Even though the sunshine is burning their skin, their spirit to work is never burned since they have to help the economy of their family without forgetting their women nature. The creation of this dance is completely the reflection of women in Brebes regency who were often seen by the dance creator, Suparyanto.

Topeng Sinok dance is a group dance which is showing the cheerfulness of a group of women. Therefore, this dance cannot be danced by one dancer. The form of this dance refers to an actual daily activities which is often called as representational. Topeng Sinok dance is female dance which is clearly illustrated in the term 'sinok' itself. Further, topeng Sinok dance has its own characteristic which is wellknown as Topeng Sinok dance style. Besides the dance style, the audiences are also attracted with the make up and costumes worn by the dancers. Both make up and costumes are attractive in colours, design, and the wearing technique. The costumes and colour selection have to be appropriate with the theme of the dance which will be performed. It purposes to strengthen and clarify the role of the dancers. The music is also an integral part of the dance since dance and the music are harmonious combination. Besides having a significant role as the musical accompaniment, music also has a role to emphasize the atmosphere of the dance. In addition to costumes or music is the dance properties. This is needed to picturize the meaning behind the dance. The underlined point in Topeng Sinok dance is the mask used in the performance of the dance. Not less important in this dance is the performance technique of the dance which has coloured the performance.

According to Supanggah (cited in Prihatini, 2007, p. 42-43), style is a distinctiveness or specificity which is characterized by physical characteristics, aesthetics (mu- sical), initiative, and individual creativity (music players), group (art society or cultural religion) which their existences are acknowledged or potentially influencing individuals, group (society) or a region (culture, music, art), whether it applies intentionally or not, nor is happening on the results of the various ways or assistance of various means of media. Sedyawati (1980, p. 5) explains that the style is the nature of the dance. It closely relates to the way to move on certain movements. Dance movement has three basic aspects, there are: power, space, and time.

The characteristics of certain dance style are highly influenced not only by the geographical aspect of where the dance is created, but also by the cultural system of the society, the daily activity pattern, as well as the societal value of culture. A dance is based on a certain dance movement technique and imbued by an inner attitude which is called dance technique. The dance technique can be elaborated into several aspects. The dance technique is a way of executing dance movements precisely, so that the desired shape and style can be achieved. As for the aspects comprise, as follows: proper posture, neck, head, arm, and leg. In another word, it means the proper rhythm in doing a series of movement. The next is to create qualities of the movements or the proper feel which is right to the certain parts of the dance. According to Jazuli (1994, p. 32), the difference of dance is not in the series of dance without any meaning attached to it, but it presents as a totality. It is the manifestation of a series of the style symbol of space and time. Therefore, dance is supposed to be seen as its whole appearance. From the choreographic point of view, there are two kinds of dance: single choreography with a single performer with the free concept in deciding the steps and group choreography which is performed by more than one dancer. Usually in a group choreography, dancers have to be the main subject of the dance. The type of group choreography is divided into three. The first is a couple dance which is performed by a couple of male dancers, female 
dancers, or male and female dancers. In this type of dance, dancers are expected to interrelated and respond to one another. The second is a group dance which is a dance performed by more than three dancers. The last one is mass dance, this type of dance is performed by the massive number of dancers.Here, the Topeng Sinok dance will be studied through the main aspects of movement and the supported aspects, such as: the musical accompaniment, make up and costumes, properties, as well as staging technique. The dance style of the body which has a role as the instruments, comprises: arms, legs, body, and head (Hutchinson, 1997, p. 500; Suharto, 1990, p. 15). The main aspect of movement encompasses power, space, and time (Hadi, 2003, p. 50; Hawkin, 1988, p. 5). The power aspect includes intensity, accent or power of movement, and movement quality. Space aspect contains volume, line, direction, and level. Time aspect includes rhythm, tempo, and duration (Murgiyanto, 1983, p. 17).

Previous study about Topeng Sinok dance was conducted by Kalihna (2015) entitled "The New Creation of Brebes Topeng Sinok Dance". In this study, it was explained that Topeng Sinok dance picturized beautiful, elegant, and skilful women. This dance is also projected as one of the typical dance of Brebes regency. Yet, the claim delivered by Kalihna has not completed Therefore, it is expected that this study can complete the previous study from the dance style's point of view.

\section{METHOD}

In conducting the study, qualitative method is implemented by using a choreography approach to aesthetical structures. Based on Brown and Royce (1976, p. 69), the structure is a unit system of relationships between existing entities. "Structure" refers to relationship management between parts of a whole system. The term aesthetic choreography itself was initially used by Hersapandi (2007, p.8-10) to analyze the aesthetical aspect of puppets through its choreography element. The second is the aesthetical aspect which is seen from its choreography aspect. Thus, choreography approach to aesthetical structures in this study means to analyze the characteristics of beauty of Topeng Sinok dance through its choreography structures; comprises movement, music accompaniment, costume, staging technique, dancer, and property. Data collecting technique which was conducted by researcher were observation, interview, and documentation. Moreover, data were validated by implementing the source triangulation technique. The data analysis technique was adopting the theory from Adshead (1988, p. 25) which was previously cited by Murgiyanto (2002, p. 9-10). The theory is divided the dance analysis into four stages:

1. Identifying and describing components

2. Understanding relationship between components

3. Interpreting the dance based on the concept and sociocultural background, performance concept, style and genre, the$\mathrm{me}$, and specific interpretation concept

4. Evaluating.

\section{RESULTS AND DISCUSSION}

\section{Review of Topeng Sinok Dance Style}

The following is an explanation of the main aspects of each range of movements in Topeng Sinok dance:

\section{Entrakan}

This movement is done by jumping. In this movement, the dancers are doing menthang, slanting backwards while miwir sampur which is holding the sampur in the very end of the sampur with right hand and the left hand is holding the mask. Sampur itself is a cloth used by the dancers. Usually it is hung at the dancer's waist. The way of holding the mask is by holding the chin of the mask. While doing that movements, the dancer is walking aside and jumping by using small movement intensity. In different words, in this movement, the left hand is doing mentang to the right side with the position miwir sampur while the 
left hand is folded and holding the mask. Furthermore, the right hand is obliquely backwards with medium movement volume. The dancers are standing obliquely to the left side and the body is facing obliquely to the right while their feet are doing left tanjak. During this style, the tempo is slow and dynamic, so that the movements keep steady. This movement gives a calm impression. When the dancer is doing left tanjak, the feet of the dancers are moving in small movement intensity. Therefore, slow movement will be seen in this entrakan movement. Accent or pressure which is done by dancers while turning their heads is by moving their head facing to the left and right side. The dancers are facing to the oblique side. The line established from this movement is diagonal. The dancer's right hand is maintained with considerably huge volume.

\section{Jengkeng}

This movement is done during the preparation of putting on and off the mask to the dancers. Jengkeng is a kind of movement done while the dancers are in sitting position where the body is resting on the right leg and the left leg is folded. The movement intensity in during this movement is small movement and small movement volume. Furthermore, medium tempo is employed in this movement. This movement gives the impression of shy since during this movement the dancers are facing backward with the hand is furling to the front of the dancers. Small movement intensity with the leg in closed position here gives the delicate impression to the dance. Accent or pressure of the movement is placed before and after the dancers are doing jengkeng, particularly when the dancers are turning around the body from the upward to the backward and vice versa. The movement line created in this movement is one straight line and direction toward straight ahead with small movement volume. The position of the hand is folded upward and not widening either to the right or left side. This movement is employing lowlevel movement since the knee is touching the floor. This movement is done in turns between dancers while they are all facing backward. By creating the patterns in turn, therefore, the audiences will not realize that the dancers are about to put on the mask. However, when they are releasing the mask, they do it together while facing backward.

\section{Gambul and Obah Bahu}

The Gambul is head movement, precisely, it is the movement while the dancers are shooking their head by heading the head and forming number eight in sleeping position. This movement is done in $3 \times 8$ counts, when it comes to count 1 to 4 there will be only the head which is moving then in count 5 to 8 , it is done with the shoulder movement. Shoulder movement is the movement where the shoulder is moving up and down following the sound of kendhang. The small movement intensity of this movement is only seen in the head and shoulder, the small volume movement realizes in the position malangkerik done by the dancers. Malangkerik is the hand movement when the hand is folded and placed aside and usually done in slow motion. Impression raised from this movement is teasing since the dancers are moving their shoulders while doing this movement. The intensity of the movement is medium because it only needs the power to move the head and shoulder. The leg movement is only by doing left gejug and the dancers are not moving but staying at their initial place. The accent of pressure of the movement is placed in the shoulder by stomping it following the musical instrument, which is kendhang. The dancers are facing forward. The direction of movement is emphasized on the shoulder movement and it is usually known as obah bahu. The body position of the dancers is mendhak while the leg position is gejug. It is done on the spot using low level movement.

\section{Lontang Sampur}

This movement is emphasizing on the hand movement, kebyok, and pushing the hand downwards in turn while ended 
by seblak sampur without releasing the sampur. Further, these movements implements parallel position for the leg and mendhak for the body, while the shoulder is moved to the right and left side in turns. The head is then moved, facing to the right and left. Accent or pressure employed in this movement is by pushing hard the hand to the waist when taking the sampur right before doing lontang sampur. The dancers are facing forward with the head is placed obliquely facing the hand which is pushed downward. The movement direction of the dancers is a straight line. It is clearly seen as the body of the dancers is upright facing forward. Here, the movement volume is emphasized in mendhak position of the leg movement. The power employed in the movement is medium, underlining the hand movement. In the hand movement element, it moves diagonally forward in slow tempo in order to create a delicate impression.

\section{Jalan Balang Sampur}

The impression of cheerful and flirtatious can be seen from this type of movement. The movement demands for high power especially when the dancers throw the sampur and the leg is moving for couple steps (double steps). The movement volume is medium since the movement of the hand while throwing the sampur is fast upward oblique. This movement is the same as the previous movement, balang sampur. The difference is on the moving movement. While balang sampur is done on the spot without moving any single step, in this movement, the dancers need to walk to move. The left hand of the dancer is ngrayung while holding the sampur and the right hand is doing ngolong sampur. This movement is done in with both hands alternately and added with the movement of seblak sampur without releasing the sampur. The movement intensity is high because the dancers need huge power to move from one place into another place. The movement intensity while the dancers are throwing the dancers itself is medium. Moreover, the direction in this movement is turning around. Round line gives the delicate impression towards this movement. The movement volume employed in this movemnet is medium. The level itself is high level.

\section{Jinjingan}

Jinjingan comes from the word 'jinjing' which means lifting. Here, jinjingan means lifting the right and left feet alternately according to the counts. This movement is done while the right hand is doing menthang and the left one is ngrayung in front of the stomach. It is conducted alternately. The leg of the dancers in this movement is stepping aside which is usually called as enjer then one of the leg is lifted. The head is moving to the right and left while the body is doing shoulder movement. It needs fast intensity since in every movement, the dancer moves their legs, two counts to the left and other two counts to the right. Medium intensity during enjer is medium since when enjer is done, the slow tempo is employed. Medium movement volume is emphasized while stretching their arms. There is also the impression of foppery when the dancers are moving around their waist while doing enjer. Accent or pressure of the movement is seen before the dancers are doing enjer, when both arms are streched while moving the head facing the right and left side alternately. At the same time, the palm is facing upward and the leg is pushed to give the show before turning the body around. Another quality is seen when the shoulders are pushed quickly while doing jinjingan. The line created from this movement is a straight movement with wide volume especially while menthang. This movement has three directions, which are straight forward, right and left side with the movement is slightly oblique to the right and left. The level of this movement itself is medium.

\section{Timbangan Asta}

This kind of movement is having the right and left hand in front of the stomach. Then, both hands are stretched to the right 
and left side then back to the front of the stomach in ngrayung position, while almost in the same time they are doing gedhek and lenggut. The legs are stepping to the right and left then standing parallel and stepping backward to the right and left then standing parallel. Timbangan asta movement is conducted while two dancers re facing one another and the hands are ngrayung to the upward and then ngrayung in front of the stomach. The legs are stepping upward and backward from 1 to 4 counts. This movement has big intensity since it tells about happiness between friends. The accent or pressure in this movement is emphasized on the head movement, which are ghedek and lenggut while moving the head to face the right and left side then to face the front. The volume of this movement is wide volume at medium level.

\section{Lontang Asta}

In doing this movement, the dancers have to do the movement as if they are chopping grass in the Indonesian traditional way. While doing this movement, the legs are mendhak and the hands are lontang while the right hand is malangkerik and the left hand is mbabat, and it is conducted alternately. The legs are stepping the floor four times in four counts, then stepping to the right side and stepping the floor as the same as previous counts, and stepping to the left side, and doing the same again in four counts. The impressions emphasized in lontang movement are delicate and flirtatious. In lontang asta, the movement intensity is big, it pictrurizes the movement of chopping the grass with the position of the hand is ngrayung and the other hand is malangkerik. It is done alternately. The movement volume is medium wiht the hand is ngrayung to the front in oblique position and the other is doing malangkerik. The movement tempo is slow but dynamic. The accent or pressure of the movement is emphasized in the head. In this movement, the head is shooked around. The line emphasized in this movement is straight line since the dancers are facing the front, and the movement direction to the right and left side. The movement volume used in this movement is medium. However, while doing mbabat, the position of the hands is oblique to the up front, and the level of the legs is medium since the legs in this position is doing mendhak.

\section{Ukel Karno Ngunus Tutus}

This movement is doing ukel on the hand to the side of the right and left ear alternately. The body movement is ogek lambung. The head movement is to move the head to face the right and left side. The leg movement is right gejug where the leg is stepping hard to the floor and on the fourth count, the dancers are timpuh where the legs are folded and the knees are touching the floor while the body stays upright. It is done in four counts alternately. Impression raised from this movement is gentle which specifically tells about the gentleness of the women while doing their work. This movement has a slow tempo in every movement done by the dancers. This movement is done with ukel movement where the hand is pulling back to the ears after that it stretched with the right hand ngrayung and the left hand is ngiting. The movement intensity of this movement is small. There is movement accent or pressure in this movement which is when the hands are about to reach the rope attached in the mask. During the time, the changing of music tempo is happened and is faster. Therefore, the volume of the movement is getting bigger and the direction of the dancer is facing forward. The movement level is both medium and low. The medium level is when the dancers are mendhak and the low level is when the dancers are timpuh. Since the movement is conducted in two levels, so it is done alternately. It is done in four counts for the medium level when the dancers are doing ukel karno while standing and four counts when they are doing obah lambung in sitting position.

\section{Nandur}

This movement has its own characteristics in Topeng Sinok dance. This movement draws a girl who is planting the 
rice. This movement is also the depection of most of Brebes women who are farmers. Here, the creator creates the movement at the same as the actual movement of planting rice in order to make people understand the dance easier. The movement here is ngiting, the right hand is moving oblique downward and the left hand is folded in front of the body. The body itself is mendhak with the body standing oblique slightly aside. The impression of the movement is firm and dynamic since the intensity of the movement is big. Furthermore, as for the movement volume in this moment is medium with on the spot movement. During the shift of the movement, the dancers are moving slowly with jumping slightly aside. This movement has medium tempo. The movement intensity is medium with cheerful movement. There is medium accent or pressure in seblak movement before getting to nandur movement. It purposes as the distinctive movement before and after the main movement. Movement volume during this movement is big. The movement direction in the hand while nandur is heading aside backwardand oblique alternately. The hand is acted as if the dancers are holding the seeds with the position of the hand is folded to the front and the fingers are ngithing in front of the chest. Also, while doing this movement, the legs are moving double step to the right and left side while doing gejug alternately. The direction of the dancers are facing to the bottom front and the level is medium. The head is nengkleng or moving to the right and left.

\section{Kebyok}

Intensity as well as tempo of this movement is big. It can be seen when the dancers are doing tracet oblique backward in order to leave the stage. The movement volume is medium. This movement comprises the movement of the hands by doing ngrayung with the sampur. The legs are tiptoeing and the head is facing the left side. From the intensity point of view, this movement belongs to strong movement in fast tempo. The movement volume is small in medium level. It is because even though the dancers are tiptoeing, however the dancers' knee are folded. In this movement, the dancers are traced to the backward with the oblique movement direction. The accent or movement pressure in this movement is medium, especially when the dancers are turning around and doing jengkeng when they are about to put off the mask.

Overall, the range of movement in this dance comprises 24 different movements which are divided into three parts. There are six movements in the initial part of the dance, twelve main movements, and six as the closing movement of the dance. In each range of motion, there are variations to make the dance more interesting. The range of movement gives the impression of flexibility, gentle, and cheerful, so that people will not be bored. In other side, doing all the movements need more time to perform. From the total 8 minutes 30 seconds of performance, the dancers will have to wear the mask for 5 minutes. Overall, almost all movements in this dance are in medium tempo since it gives the impression of cheerful but calm at the same time.

Supporting aspects: Topeng Sinok dance has several supporting aspects. It encompasses: (1) make up and costume (2) music acompaniment (3) property, as well as (4) Staging technique, as follows:

\section{Make Up and Costume}

The dancers on Topeng Sinok dance are wearing corrective makeup, which is made up emphasizing the beauty of the dancers. It beautifies the face of the dancers in order to make them look fresh and beautiful on the stage. Whereas, for the mask, character type makes up is applied. The character raised on the mask is a cheerful but gentle type of women. Through the mask's make up, the creator of the dance can emphasize the character of the Tobin Sinok dance. In other words, it can be said that the make up which is put on the mask has its own strength and beauty which brings the character of the 
dance. Moreover, for the costume worn by the dancers on stage, bright colours are chosen. It brings the impression of cheerful and draws female figure well. Usually, the colours of the costumes are pink and yellow.

\section{Music Accompaniment}

Topeng Sinok dance uses Javanese rhythm, irama and tanggung. The tempo is fast the dance is lively. There are high and low tempo dynamics in the middle of the song that makes the dance more attractive. In addition, music accompaniment in Topeng Sinok dance has its own characteristics. The lyrics are used Brebes traditional language, ngapak, and it is sung by a man and woman singers. The aim is to introduce Brebes's traditional language. Music is started with kendang, which is to emphasize the starting part of the music. Kendang sunda is used in this music to emphasize the cheerfulness of the dance.

\section{Lancaran Sinok PL Nem}

Buka: kendang $p$ t $p$ t $p p p$

- . 1

$\begin{array}{llllllllll}. & 1 & .1 & .12 & 32 & 1 & .1 & .12 & 35 & 6\end{array}$

. $56 \quad .56$. $56 \quad 54 \quad 6$

A irama lancar (1)

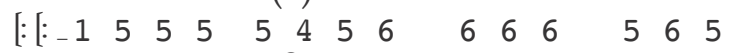
$\begin{array}{llllllll:}6 & 5 & 6 & 5 & 4 & 6 & (5) & :]:]\end{array}$

Gerongan:

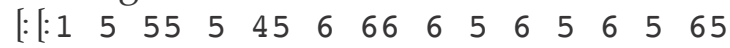
46 : $5:$ :]

Sinok noknoknok cah ayu yuyuyu Mesem guyu menggoda hati ku

B irama tanggung $(1 / 2)$

$\begin{array}{lllll}465 & -465 & -465 & 245 & 6 \\ 666 & -5456 & -666 & 542 & 4 \\ 542 & -542 & -.12 & 123 & 1 \\ .21 & -2321 & -121 & 216 & 5\end{array}$

\section{Gerongan}

$\left[\begin{array}{llllll}: & .465 & .465 & .465 & 245 & 6\end{array}\right.$

Siñk cahayu săpa jenengan mu

$\left[\begin{array}{lllll}: 6666 & 5456 & .6 .6 & 542 & 4\end{array}\right.$

Ora me sem ora gu yu meng go da ha ti ku

$\left[\begin{array}{llllll}.542 & .542 & 2.12 & 123 & 1\end{array}\right.$

Kepriben ka rep mu mas a pa se neng aku

$\left[\begin{array}{lllllll}. .21 & 2321 & .121 & 216 & 5\end{array}\right.$

Angger seneng a ku ngmong a wong tu aku
"Sinok nok nok orang cantik tik tik tik

Tersenyum tertawa menggoda hatiku

Sinok nok nok orang cantik tik tik tik

Tersenyum tertawa menggoda hatiku

Sinok nok nok orang cantik tik tik tik

Tersenyum tertawa menggoda hatiku

Sinok orang cantik siapa namamu

Tidak senyum tidak tertawa menggoda hatiku

Gimana inginmu mas apa suka aku

Kalau suka aku bicara dengan orang tuaku"

"Beautiful girl

is smiling and teasing my heart

Beautiful girl

is smiling and teasing my heart

Beautiful girl

is smiling and teasing my heart

Beautiful girl what is your name?

is not smiling and is not teasing my heart

What do you want, dear? Do you like me?

If you do, go talk to my parents

\section{Property}

The properties used in this dance is mask. It is used to support the expression of the dancers. The mask itself is used gentle female make up with white as the colour foundation. An impression of beauty in the mask can be seen from the draw of the curve eyebrow since it picturize cheerfulness in every movement of the dance. There are red and white circles in the ear of the mask. The colour background of the mask is white, the eyes are small but widening picturizes the tenderness and elegance of a princess. Different from other masks, the mask has a kind of head ornament attached to the mask. To be noted, in Indonesia, the head ornament is normally worn by the dancers, however, in this dance, it is attached to the mask instead of the dancers.

\section{Stage}

Topeng Sinok dance can be performed in procenium type of stage which is stage which can be only view from the front side only. This also can be called as framed stage. Further, this dance can be also enjoyed in outdoor stage although the dancers can only face the front side. This 
dance is also static. It means, it can be only enjoyed when the dancers are on stage and cannot be enjoyed in series of parade.

\section{CONCLUSION}

Topeng sinok dance movement is seen in the basic aspect of movement, costume and make up, music accompaniment, and property. Movements in Topeng Sinok dance is done by body elements, such as: hands, legs, shoulders, and head with small intensity, full of movement accent, small movement volume with fast tempo and happy music atmosphere. A costume worn in this dance is bright and the mask has white colour foundation on it with a black gold eyebrow. Among all, it shapes a beautiful, elegant, tender, cheerful, and skilful dance.

\section{REFERENCE}

Adshead, Janet (Editor). (1988). Dance Analysis. Cambridge: Oxford University Press.

Astiri. W. \& Budiarto, C. (2013). Semiotika Rupa Topeng Malangan (Studi Kasus: Dusun Kedungmonggo, Kec. Pakisaji, Kabupaten Malang). Journal Ruas, 11(2), 89-98.

Diah, A. (2007). Makna Simbolis pada Unsur Visual Kostum Tari Topeng Babakan Cirebon Keni Arja di Desa Slangit. Journal of Visual Art and Design. 1(2), 224-245.

Hadi, Y. Sumandiyo. (2003). Aspek-aspek Dasar Koreografi Kelompok. Yogyakarta: Elkaphi
Hawkins, Alma M. (1988). Creating Through Dance. New Jersey: Princeton Book Company.

Hersapandi, (2007). “Kehidupan Wayang Wong Sriwedari dalam Perspektif Seni Pertunjukan dan Pariwisata. Jakarta: Penelitian Hibah Kompetensi Dirjen Dikti.

Hutchinson, Ann. (1977). Labanotation or Kinetography Laban: The System of Analysing and Recording Movement. New York: Theatre Arts Books 153 Waverly Place.

Jazuli, M. 1994. Telaah Teoritis Seni Tari. Semarang: IKIP Semarang Press

Murgiyanto, Sal. (1983). Koreografi. Jakarta: Dirjen Pendidikan Dasar dan Menengah Depdikbud.

Mugiyanto, Sal. (2002). Kritik Tari Bekal Dan Kemampuan Dasar. Jakarta: Masyarakat Seni Pertunjukan Indonesia.

Prihatini, S. Nanik. (2008). Seni Pertunjukan Rakyat Kedu. Surakarta: Pasca Sarjana and ISI Press

Ratnaningrum, Ika. (2011). Makna Simbolis dan Peranan Tari Topeng Endel. Harmonia: Journal of Arts Research and Education, 11(2), 125-129

Royce, A. P. (2007). Antropologi Tari. Terjemahan F.x. Widaryanto. Bandung: STSI Press.

Sedyawati, Edi. (1980). Pertumbuhan Seni Pertunjukan. Jakarta: Sinar Harapan

Suharto, Ben. (1990). Pengamatan Tari Gambyong Melalui Pendekatan Berlapis Ganda. Paper presented on Temu Wicara Etnomusikologi Indonesia 3, 2/5 February 3, 1987 in Medan. 